\title{
Finding the presence of God in investor's heart: examining the link between religiosity and socially responsible investment
}

\author{
Tegar Satya Putra ${ }^{1}$, Marwan Asri ${ }^{2}$ \\ ${ }^{1}$ Program Studi Manajemen, Fakultas Bisnis dan Ekonomika, Universitas Atma Jaya Yogyakarta \\ ${ }^{2}$ Program Studi Manajemen, Fakultas Ekonomika dan Bisnis, Universitas Gadjah Mada \\ *Corresponding author: tegar.satya@uajy.ac.id
}

\begin{abstract}
Socially Responsible Investment or ethical investment has grown significantly in various countries. This rising trend creates a big question mark in the head of investors and finance scholars as the concept of ethics and investment has not been widely discussed in the finance literature. The discussion mostly focuses on the demographic characteristics of socially responsible investors and there is only a handful of literature which discusses the within-person factors that influence an investor to invest in SRI. Based on those notions, this paper examines the relationship between investors' religiosity with their decision-making process in SRI. Religiosity is chosen as the possible antecedent because religiosity has discussed widely in the business ethics literature as one major antecedent in an ethics-related construct. It is found that Religiosity does influence investors decisionmaking process indirectly through their decision frame.
\end{abstract}

Keywords: Socially Responsible Investment, Ethical Investment, Green Investment, Religiosity, Behavioral Finance

\section{Abstrak}

Socially Responsible Investment (SRI) atau investasi beretika telah berkembang sangat pesat di berbagai negara. Tren ini membuat para investor dan ahli keuangan bertanya-tanya karena konsep etika dan investasi belum banyak dibahas dalam literatur keuangan. Diskusi mengenai mengenai SRI masih berfokus pada aspek demografis dari investor $S R I$, hanya beberapa literatur yang membahas mengenai faktor-faktor within-person yang mempengaruhi investor untuk berinvestasi dalam produk yang digolongkan sebagai SRI. Berdasarkan hal tersebut, penelitian ini menganalisis hubungan antara religiositas seseorang dengan niat orang tersebut untuk melakukan SRI. Religiositas dipilih sebagai anteseden karena dalam literatur etika bisnis konstruk ini terbukti memengaruhi perilaku etis seseorang. Dari hasil uji yang dilakukan dalam penelitian ini, religiositas terbukti sebagai anteseden tidak langsung dari niat seseorang untuk melakukan SRI.

Kata kunci: Socially Responsible Investment, Investasi Beretika, Investasi Hijau, Religiositas, Keperilakuan Keuangan JEL: G41 DOI: 10.20885/jsb.vol23.iss1.art2

\section{Introduction}

Socially Responsible Investment (SRI) or ethical investment has been under scrutiny from both investors and finance scholars (Revelli \& Viviani, 2015). SRI has grown significantly in the past decades in several countries. In the United States, the value of SRI held by both individual and institutional investors is around 5 trillion USD (Williams, 2007). SRI also has gained popularity in countries outside the USA such as Canada (approximately 530,9 CAD) and Asia (approximately 40,8 million USD) ( Williams, 2007; Revelli \& Viviani, 2015).

Other than the rising value of SRI, finance scholars put special attention to SRI because they consider it as an anomaly in finance theory. Finance theory, which rooted in financial economics, holds a strong assumption in regards to people's rationality in forming the theory that we know in the present. One of the commonly believed theorems is the separation theorem (Glac, 2012). This theorem postulates that in an efficient market people process consumption and investment decision separately. 
Finding the presence of God in investor's heart: examining the link between religiosity and socially responsible investment

If the theorem holds, when investors are making an investment decision, non-financial information should be excluded or else the investors would only get a sub-optimal portfolio (Hylton, 1992). Despite this theorem is widely believed, this rising trend of SRI and the incapability of finance theory to explain SRI phenomenon leave a theoretical gap in which finance scholars have tried to bridge in recent decades (e.g.: Adam \& Shauki, 2014; Diouf, Hebb, \& Toure, 2016; Gardner, 2004; Glac, 2009, 2012; Revelli \& Viviani, 2015). Nevertheless, the focus of research in SRI mostly on the performance of SRI and the demographic factors concerning SRI (Glac, 2012). There is only a handful of research that examines the within-person factors that influence a person to invest in SRI (Glac, 2009, 2012).

One of the few works of literature on within-person factors which influence investors' decision in conducting SRI is the work by Glac $(2009,2012)$. She finds that the decision to conduct SRI depends on the decision frame of the investors. Decision frame is defined as a product of the cognition process within people (Glac, 2009). The process integrates all relevant information regarding a situation in which people have to make a decision. Decision frame has become an established concept in behavioral literature such as organizational and managerial behavior (Walsh, 1995). In the SRI context, Glac $(2009,2012)$ reveals that there are two types of decision frame, the non-SRI investors have the "financial decision-frame" and SRI investors have the "integrated investment frame". The type of decision frame which investors have depends on several factors. One of the factors that have been proven empirically is morality (Glac, 2009, 2012; Lewis, 2001) but there are several possible antecedents which need to be empirically tested. Based on that, we extend the work of Glac $(2009,2012)$ by examining the antecedent of investor decision frame. The possible antecedent chosen in this literature is religiosity.

The role of religiosity in the decision-making process in the business context has been acknowledged by business management scholars such as Hunt \& Vitell (1992). They incorporate religion as one of the main factors that influence ethics related construct in the theory of general marketing ethics. This seminal work becomes the milestone for several business ethics scholar in finding the answer of a person's religiosity role in business ethics context. (e.g.: Arli \& Tjiptono, 2014; Pace, 2014; Schneider, Krieger, \& Bayraktar, 2011; Vitell, Singh, \& Paolillo, 2007; Walker, Smither, \& DeBode, 2012). Despite that, a consensus about the role of religiosity in business ethics has not been found (Arli \& Tjiptono, 2014), which open another research gap that has to be filled by business ethics scholar.

We try to fill the research gaps explained above, by examining the role of religiosity in SRI or ethical investment as there is a need to examine investors decision-making process in SRI. Furthermore, this research is conducted in Indonesia as Indonesia is the real example in which the contradiction between religiosity and ethics happens. The state has a high number of people who place their faith in religion, despite that, the unethical conduct (e.g: corruption, piracy) in Indonesia is widespread (Arli \& Tjiptono, 2014; Arli, Tjiptono, \& Porto, 2015).

\section{Literature Review}

The role of religiosity in the ethical decision making is explained in the revised version of the general theory of marketing ethics (Hunt \& Vitell, 1992), although the theory focus in marketers and consumers decision making in business ethics context, the theory provides a framework in examining investors decision-making process in the context of SRI. The theory explains that when people face a situation in which an ethical consideration is needed, the people will do two types of evaluations, they are: deontological evaluation and teleological evaluation, after people do both types of evaluation, ethical judgment of the situation is formed and this judgment will shape people intention to conduct a specific behavior. Deontological evaluation is an assessment of the situation based on the personal value of the decision makers who face the situation, while teleological evaluation is an assessment of the situation based on the consequences of the decision to the people surrounding the decision makers (Hunt \& Vitell, 1986). Based on the general theory of marketing ethics, the evaluations are influenced by five factors, they are the cultural environment, professional environment, industry environment, 
organizational environment, and personal characteristics. Below is the conceptual framework of the general theory of marketing ethics.

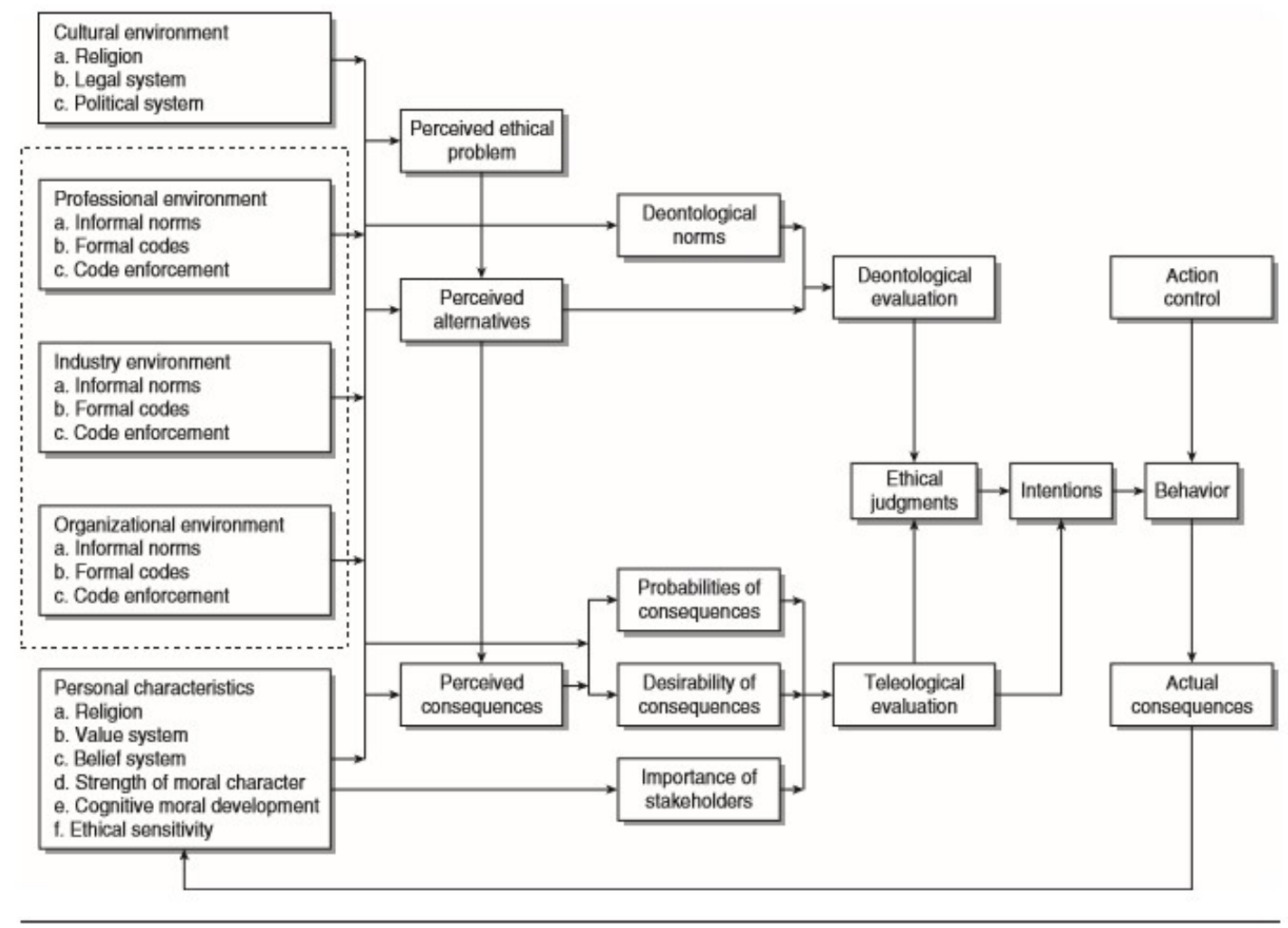

Figure 1. General Theory of Marketing Ethics

Source: ( Hunt \& Vitell, 1986, 1992, 2006)

\section{Religiosity}

Religiosity has been considered as an important social institution which influences the individual decision-making process (Kennedy \& Lawton, 1998). This research uses the definition of religiosity by Allport \& Ross (1967) who divided religiosity into two dimensions, they are intrinsic religiosity and extrinsic religiosity. Intrinsic religiosity is defined as the extent to which people live in their religious values, while extrinsic religiosity is the utilitarian (usefulness) dimension of religiosity (Allport \& Ross, 1967). An extrinsically religious person conducts religious activities for gaining the benefits related to those religious activities (e.g. peaceful mind, making friends, social acceptance). Meanwhile, a person who has high intrinsic religiosity values their relationship with God more than the benefits that they got for joining in religious activities.

Several works of literature in business ethics have examined the effect of both extrinsic and intrinsic religiosity in several ethics-related constructs such as ethical belief ((Arli \& Tjiptono, 2014), ethical ideologies (Arli \& Pekerti, 2016), and ethical intention (Singhapakdi, Vitell, Lee, Nisius, \& Yu, 2013). Based on those several works of literature, it is found that intrinsic religiosity influences one's ethical standard, attitude, and behavior in a positive manner. It is found also that extrinsic religiosity has no effect on the ethics-related construct (Arli \& Tjiptono, 2014; Kennedy \& Lawton, 1998). Therefore, this research excluded extrinsic religiosity because this dimension of religiosity does not influence a person's belief and decision making. 
Finding the presence of God in investor's heart: examining the link between religiosity and socially responsible investment

\section{Socially Responsible Investment}

Socially responsible investment is defined as investment activity which considers non-financial criteria in doing the activity (Renneboog, Ter Horst, \& Zhang, 2011). The non-financial criteria are Environment, Social and Governance (ESG factor). Investors can conduct SRI by investing in SRI mutual fund or screening a financial instrument which complies with ESG criteria.

As stated in the introduction part of this paper, SRI has become a trend in investment nowadays. The trend has raised questions for finance scholars and investors as this type of investment cannot be explained by conventional finance theory. Conventional finance theory which rooted in financial economics has a strong assumption on human rationality (Glac, 2009). Holding this assumption, investors must not consider non-financial criteria when they have to make an investment decision as non-financial criteria are not relevant in investment. The inclusion of non-relevant criteria in investment decision making will impede investors to achieve maximum utility (Hylton, 1992). The failure of conventional finance theory signals for the need for a more behavioral approach in SRI research.

In Indonesia, SRI has not well established compared to the Anglo Saxon countries such as the US and UK, as Indonesia still does not have SRI mutual fund (Williams, n.d.). Despite having no SRI mutual fund, Indonesia has a stock index for SRI stock called SRI Kehati Index. SRI Kehati index is established by the collaboration between the Indonesia Capital Market (IDX) and Yayasan Kehati. The index consists of 25 companies which are adjusted biannually. The screening process is based on both financial and ESG criteria. The financial criteria are 1). Market capitalization value should be more than 1 trillion; 2) the total assets of the company should be more than 1 trillion, and 3) free float rate of shares must be more than $10 \%$. Meanwhile, the ESG criteria used in the sorting process are: 1) The company's core business is not in the category of pesticide, nuclear, weapon, tobacco, alcohol, pornography, gambling, and genetically modified organism (GMO) businesses. GMO is the modification of animal genes to obtain the 5 desired characteristics; 2) overall companies activities must be qualified in various aspects such as corporate governance, community involvement, fair and ethical business conduct, and 3) human resource management that concerns human rights in its implementation.

\section{Investment Decision Frame}

Psychology literature suggests that there are two main stages in the decision-making process. The first stage, when a person faces situations that require him to make a decision, he arranges the information contained in the situation. Structuring this information is useful to determine which information is relevant. In the second stage, the individual integrates the information into a frame or mental model. The integration also takes into account the preferences and values (e.g.moral) held by the individual ( Pitz\& Sachs, 1984). This frame gives a meaning of the condition he/she is currently facing (Pitz \& Sachs, 1984). The decision frame is what will affect a person's decision making. Each person has different decision frame in the same circumstances. Differences in decision frame across individual are the source or variability of decision across individual (Bagdasarov et al., 2016; Glac, 2009; Westbrook, 2006).

In the context of SRI, Lewis (2001) found that investors decision to engage in SRI activity depends on the investment decision frame that the investors have. Investment decision frame is how investors define the meaning of investment for themselves. Lewis (2001) concludes that there are two types of investment decision frames:

1) Financial investment decision frame

Investors who have this decision frame will assume that all decision they make in the field of investment is based only on the financial information of the firms or the securities (Glac, 2009).

2) Integrated investment decision frame

Investors who have this type of decision frame see investment as an extension of, value, and belief that they hold (Glac, 2009; Lewis, 2001). This mental model is similar to the mental model often 
discussed in the field of consumer ethics (Glac, 2009). Therefore, we refer to some consumer ethics literature.

As the integrated investment decision frame is the one which shaped investor intention to invest in SRI, this type of frame is the main spotlight of this research.

\section{Hypothesis Development}

There are three hypotheses in this research. The first hypothesis concerns about the link between intrinsic religiosity and integrated investment frame, the second hypothesis concerns about the link between integrated investment frame toward intention to conduct SRI and the last hypothesis concern about the mediating role of integrated investment frame in the relationship between intrinsic religiosity and intention to conduct SRI.

The value of religion will affect ethical judgment, ethical belief, and ethical behavior. The notion is proven empirically by several works of literature in business ethics (see: Arli \& Tjiptono, 2014; Singhapakdi et al., 2013; Vitell, Paolillo, \& Singh, 2006; Wong, 2008). If the integrated investment frame is seen as an ethical judgment about how investment should be done, then intrinsic religiosity will influence integrated investment frame. Moreover, since people who have a high religiosity is people who live in their religion (Allport, 1950), then the people will see that the investment they undertake must reflect their religious values. Based on the above then the first hypothesis in this study is:

H1: Intrinsic religiosity positively influences the Integrated Investment Frame (IIF).

As previously mentioned, how people frame/judge the situation (belief/attitude toward a situation) elicit their intention and the intention translated to specific behaviors (Ajzen, 1985; Hunt \& Vitell, 1986). The relationship between frame/attitude and intention has received a robust proof in behavioral science. In the context of SRI, the relationship between the frame in investing and intention to conduct SRI has been supported by Glac (2009) and Glac (2012) research. Based on the findings, it can be said that people who have an integrated investment frame will have an intention to conduct SRI and has more SRI percentage on their portfolio. The second hypothesis of the research is: $\mathrm{H} 2$ : Integrated investment frame positively influences the intention to conduct SRI.

Decision frame is the internal mechanism of human to integrate all information concerning a situation to give the situation a meaning (Pitz \& Sachs, 1984). After the decision frame is formed, this decision frame shapes people's intention to conduct a specific behavior. Based on the role of decision frame in the decision-making process, it can be inferred that in this research, integrated investment frame acts as mediating variable in the relationship between intrinsic religiosity and intention to conduct SRI. For a variable to be called as a mediating variable, the variable must represent an internal process that happened due to the presence of stimuli (Barron \& Kenny, 1986). We argue that integrated investment frame is the internal mechanism in processing the stimuli that investors received, as constructing a decision frame is within-person processes to construct information and stimuli that people receive, therefore, the last hypothesis is:

H3: Integrated investment frame mediates the relationship between intrinsic religiosity and intention to invest SRI.

\section{Measurement}

There are three variables in this research. All of the three variables are latent variables. A latent variable is a variable that cannot be measured directly due to the variable is a derivation from an abstract concept (Hair et al, 2014). The measurement of a latent variable is conducted by observing the indicators of the latent variable using an instrument developed specifically to measure the variable. 
We adopt instruments developed by previous works of literature in behavioral science. Intrinsic religiosity is measured using 7 items instrument developed by Allport \& Ross, (1967), integrated investment is measured by 5 items instrument developed by Glac (2012) and intention to conduct SRI is measured using 4 item instrument developed also by Glac (2012) (originally there are five items in the instrument to measure the intention to conduct SRI but we decide to delete one item as the item is not suitable in Indonesian context).

The relationship among the three variables in this research and the hypotheses can be seen in this conceptual model below:

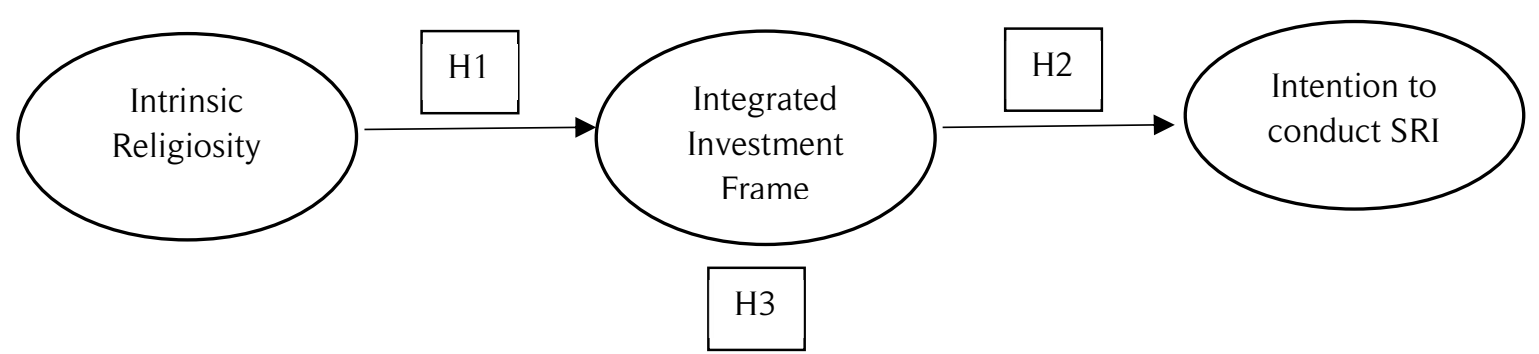

Figure 2. Conceptual Model

\section{Sample}

The object of this research is financial instrument investors. We use one of the non-probability sampling methods, purposive sampling. Purposive sampling is a sampling method where the researcher chooses his/her research object by judging whether a person fits with the overall research objectives (Neuman, 2014). The criterion used in the sampling is: the person must invest in stocks, bond or mutual fund in the capital market. In order to increase the response rate and provide an anonymous response, the questionnaire is delivered in an online manner. In the end, 206 respondents fill the questionnaire.

Majority of respondents are male. The number of male respondents is 148 people (71.8\%), while the number of female respondents is only 58 people $(28.2 \%)$. In terms of education level, respondents in this study have a level of education vary from High School Diploma to Doctorate degree. The majority of respondents have a Bachelor Degree (41.3\%), followed by respondents with High School Diploma (36.4\%), respondents with Master Degree (17\%), Diploma $(4.4 \%)$ and Doctorate Degree $(1 \%)$. In term of monthly income, the respondents in this study mostly have income between 1 million Rupiah to 3 million rupiahs $(29.1 \%)$, 59 people $(28.6 \%)$ had revenues of less than 1 million, 57 people (27.7\%) earned more than 5 million and 30 people $(14.6 \%)$ had incomes between 3-5 million rupiah.

\section{Validity and Reliability of Instruments}

The validity and reliability are checked in order to minimize the possibility of measurement error and bias. Reliability is checked using Cronbach Alpha. An instrument can be called as valid if the value of its Cronbach alpha is equal or more than 0.7 (Cooper \& Schinder, 2014). As for the validity, confirmatory factor analysis is used. In order to be called as valid, an instrument should be scored equal or more than 0.5 in its Average Variance Extracted (AVE) value. Below is the result of both validity and reliability analysis of instruments used in this research. Due to the poor level of reliability and validity of several variables, several items are deleted. Deletion of an item is justified if the deletion of item results in a higher level of reliability and validity (Hair et al., 2014). The deleted items are one item from intrinsic religiosity (IR5), two items from integrated investment frame (IIF4 and IIF5) and one item from intention to conduct SRI (INT4). 
Table 1. Validity and Reliability of the Instruments

\begin{tabular}{ccccc}
\hline Instrument & \multicolumn{2}{c}{ Cronbach alpha } & \multicolumn{2}{c}{ AVE } \\
\hline & Before & After & Before & After \\
IR & 0.758 & 0.842 & 0.389 & 0.667 \\
IIF & 0.725 & 0.818 & 0.475 & 0.773 \\
INT & 0.693 & 0.809 & 0.551 & 0.721 \\
\hline
\end{tabular}

As can be seen in table 1, after deletion of several items, the Cronbach Alphas for the three instruments are above 0.7 and the AVE of all instruments above 0.5. Based on the result, all of the instruments used in this study is valid and reliable.

\section{Result and Discussion}

In order to analyze the relationship among variables and test the hypotheses, regression analysis is used. As for the mediating mechanism, Barron and Kenny (1986) method of testing the mediating mechanism is carried out. The Barron-Kenny offer three-steps analysis to test the mediating mechanism, below is the brief elaboration of each step:

1. The first step is regressing dependent variable $(\mathrm{Y})$ and the independent variable $(\mathrm{X})$.

2. Second, the mediating variable $(M)$ is regressed to the independent variable $(X)$.

3. Third, the dependent variable is regressed to both the independent variable $(\mathrm{X})$ and the mediating variable $(\mathrm{M})$.

The mediating mechanism is proven if the beta of the independent variable $(X)$ in model 3 is lower compared to the beta of the independent variable (X) in model 1 (Barron \& Kenny, 1986). Below is the regression result to answer the first hypothesis, we also include several control variables, they are gender, years of investment experience, education level, Investment orientation (long-term of short-term orientation) and level of income.

Table 2. Regression Result for the First Hypothesis

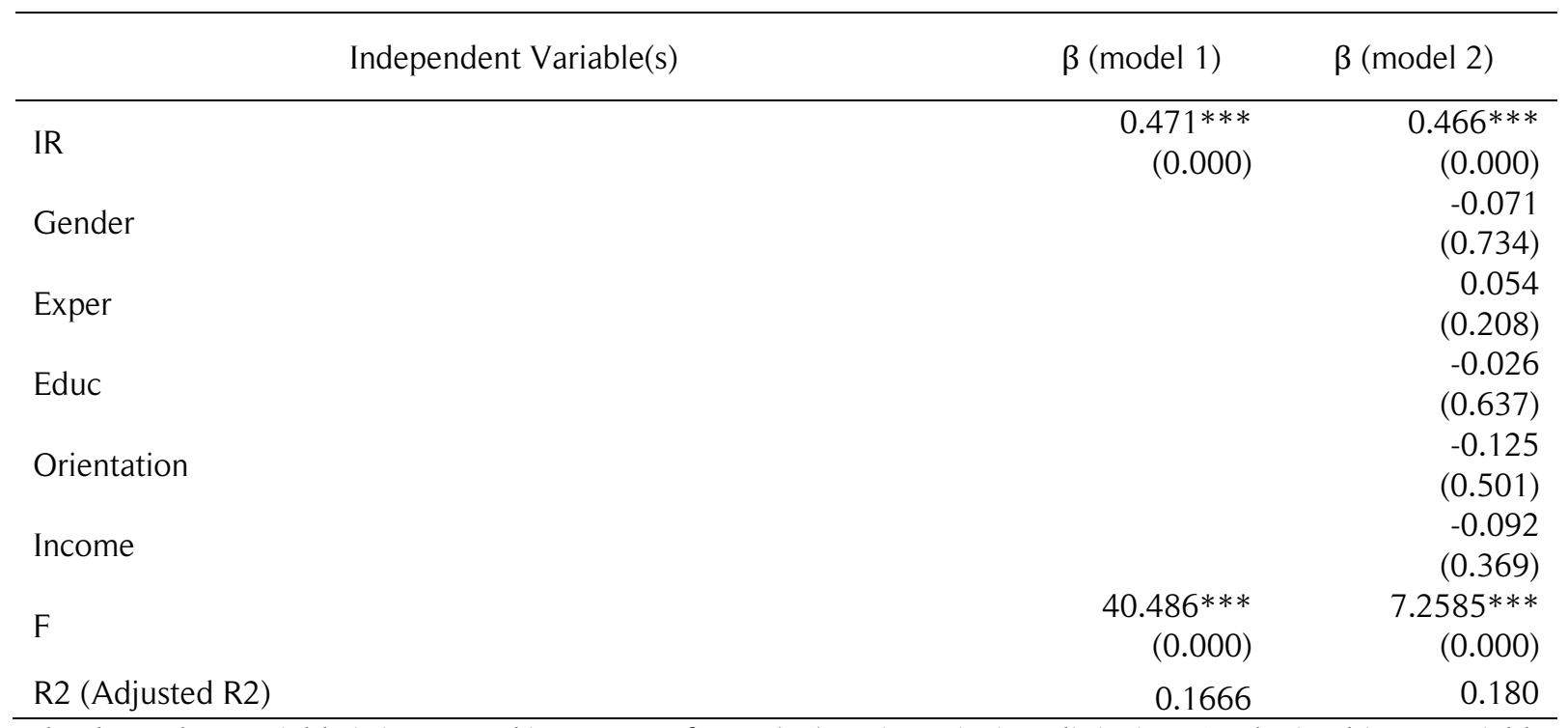

The dependent variable is integrated investment frame (IIF). IR is Intrinsic Religiosity; Gender is a binary variable where 1 is the code for male and 2 is the code female; Exper is investment experience (in years); educ is education level; orientation is a binary variable where 1 is long-term orientation and 2 is short-term orientation and the last income is the level of income. Number in the parentheses is the p-value.

$* * *$ significant at $1 \%$ level 
As can be seen in table 2, Intrinsic Religiosity (IR) significantly influences Integrated Investment Frame (IIF) in $1 \%$ level. The result is robust because IR still significantly influences IIF even after we included several control variables in model 2 . The IR betas of both models are positive which provide support for the first hypothesis. As for the goodness of fit, the r-square of both models is $16.67 \%$ (model 1) and $18 \%$ (model 2). Besides the r-square, based on the F-value, both of the models can be concluded as correctly specified as the F-value of both models is significant at $1 \%$ level.

As the regression result in table 1 suggest, the first hypothesis is supported. IR positively influences IIF. The positive relationship between intrinsic religiosity and integrated investment frame is also found by Putra \& Asri, (2018). Moreover, this finding provides support for several previous findings in the effect religiosity toward ethical belief and ethical behavior such as Arli \& Tjiptono (2014); Pace (2013); Schneider et al., (2011) (we argued that integrated investment is can be seen as one's ethical belief in investment context). The first hypothesis has been proven, the discussion then moves to the second and third hypothesis. The result of regression to prove the second hypothesis is presented in table 3 below:

Table 3. Regression result for Second Hypothesis

\begin{tabular}{|c|c|}
\hline Independent Variable(s) & $\begin{array}{c}\beta \text { (model } \\
3 \text { ) }\end{array}$ \\
\hline IIF & $\begin{array}{r}0.467 * * * \\
(0.000)\end{array}$ \\
\hline $\mathrm{F}$ & $\begin{array}{r}89.551^{* * *} \\
(0.000)\end{array}$ \\
\hline R2 & 0.305 \\
\hline
\end{tabular}

The regression result between intention to conduct SRI (INT) and Integrated Investment Frame (IIF) provides support for the second hypothesis. An investor who has a higher degree of integrated investment frame has a higher intention to conduct SRI. This conclusion is based on the pvalue of IIF beta is below than $0.01(1 \%)$. As the p-value is below $1 \%$, the beta of IIF is statistically significant. Moreover, the beta sign is positive which in line with the second hypothesis in this research. The acceptance of the second hypothesis provides support for Glac $(2008,2009,2012)$ finding. This finding also shown that how people frame/judge or evaluate an object (attitude of someone toward an object/behavior) will shape their intention to conduct a specific behavior as stated in Theory of Planned Behavior (Ajzen \& Fisben, 1985) and General Theory of Marketing Ethics (Hunt \& Vitell, 1986).

The last hypothesis is tested using Barron \& Kenny (1986) method as stated above. The second step has been done already as we tested the first hypothesis (table 1). Therefore, in table 4 below, we conduct the first and third step in order to test the mediating mechanism I $\mathrm{n}$ our model. Table 4 shows that the mediating mechanism is proven. Table 4 provides the proof of the mediating mechanism in our model. In the first step of Barron \& Kenny (1986) method, the independent variable (IR) must significantly influence the dependent variable (INT). As shown in table 4, the beta of IR is significant in $1 \%$ level regardless we included the control variables or not (model 4 and model 6), as the first step is done and the result is significant, we proceed to the second step. 
Table 4. Regression result for hypothesis 3 (mediating mechanism)

\begin{tabular}{|c|c|c|c|c|}
\hline Independent Variable(s) & $\beta$ (model & $\beta$ (model 5) & $\beta$ (model 6) & $\beta$ (model 7) \\
\hline IR & $\begin{array}{c}0.262 * * * \\
(0.000)\end{array}$ & $\begin{array}{c}0.05 \\
(0.422)\end{array}$ & $\begin{array}{c}0.260 * * * \\
(0.000)\end{array}$ & $\begin{array}{c}0.050 \\
(0.438)\end{array}$ \\
\hline IIF & & $\begin{array}{c}0.449 * * * \\
(0.000)\end{array}$ & & $\begin{array}{c}0.453 * * * \\
(0.000)\end{array}$ \\
\hline Control Variables & No & No & Yes & Yes \\
\hline R2 & 0.268 & 0.554 & 0.308 & 0.571 \\
\hline Delta R2 & \multicolumn{2}{|c|}{0.236} & \multicolumn{2}{|c|}{0.263} \\
\hline
\end{tabular}

No in control variables indicates that the control variables are included in the model. Yes in control variables indicates that the control variables are not in the model. The number in the parentheses is the p-value $* * *$ significant at $1 \%$ level

The second step of Barron \& Kenny (1986) requires a significant relationship between the mediating variable (IIF) and the independent variable (IR). In table 2, the beta of IR is positive and significant in $1 \%$ level regardless we included the control variables or not. The last step of Barron \& Kenny (1986) requires a comparison between IR betas in model 4 and 5 . The beta of IR in model 4 is 0.262 and significant in $1 \%$ level, but the beta becomes insignificant in the model 5 as we include the mediating variable (IIF). The same pattern also happens in model 6 and 7 (models where we included all control variables in the regression model). In model 6 the IR beta is 0.260 and significant in $1 \%$ level but the beta becomes insignificant in model 7 , therefore the mediating role of IIF is proven and the last hypothesis is supported. In conclusion, the IIF represents the internal mechanism in response to the stimuli of intrinsic religiosity in the investors' decision-making process.

\section{Conclusions}

The acceptance of three hypotheses implied that intrinsic religiosity does influence how investors believe investment should be done, this belief/attitude/frame toward investment will shape their intention to conduct SRI. Our finding provides support to the role of religiosity in shaping ethical behavior. The finding also provides support to the impracticality of separation theorem to explain investor behavior, as investors also consider non-financial criteria in making their investment decision. This inclusion of non-financial criteria proves that people do not separate between his decisionmaking process in consumption and investment activity.

This study has several limitations. The first limitation, religiosity is a construct which is susceptible to socially desirable bias. We have tried to reduce the likelihood of such bias by providing anonymity to the respondents in this study, but further research should use methods that can cope with socially desirable bias.

The second limitation arises from the use of the intention as a proxy of SRI behavior. We argue that the intention is the strongest predictor of behavior, but this is still debatable. There are other behavioral mechanisms that can lead to a disparity between intention and behavior. Last, we use survey method as the main data collection method. This method has a weakness in internal validity because researchers cannot control all the factors that may affect the variables used in the research. Therefore, further research can use an experimental approach to overcome this problem.

\section{References}

Adam, A. A., \& Shauki, E. R. (2014). Socially responsible investment in Malaysia: Behavioral framework in evaluating investors' decision-making process. Journal of Cleaner Production, 80, 224-240. https://doi.org/10.1016/j.jclepro.2014.05.075 
Ajzen, I. (1985). From Intentions to Actions: A Theory of Planned Behavior. Action Control, 11-39. https://doi.org/10.1007/978-3-642-69746-3_2

Allport, Gordon W. "The individual and his religion: A psychological interpretation." (1950).

Allport, G. W., \& Ross, J. M. (1967). Personal religious orientation and prejudice. Journal of Personality and Social Psychology, 5(4), 432-443. https://doi.org/10.1037/h0021212

Arli, D., \& Pekerti, A. (2016). Investigating the Influence of Religion, Ethical Ideologies and Generational Cohorts Toward Consumer Ethics: Which One Matters? Social Responsibility Journal, 12(4), 770-785. https://doi.org/10.1108/SRJ-08-2015-0112

Arli, D., \& Tjiptono, F. (2014). The End of Religion? Examining the Role of Religiousness, Materialism, and Long-Term Orientation on Consumer Ethics in Indonesia. Journal of Business Ethics, 123(3), 385-400. https://doi.org/10.1007/s10551-013-1846-4

Arli, D., Tjiptono, F., \& Porto, R. (2015). The impact of moral equity, relativism, and attitude on individuals' digital piracy behaviour in a developing country. Marketing Intelligence \& Planning, 33(3), 348-365. https://doi.org/10.1108/02634501011078138

Bagdasarov, Z., Johnson, J. F., MacDougall, A. E., Steele, L. M., Connelly, S., \& Mumford, M. D. (2016). Mental models and ethical decision making: The mediating role of sensemaking. Journal of Business Ethics, 138(1), 133-144.

Baron, R. M., \& Kenny, D. A. (1986). The Moderator-Mediator Variable Distinction in Social Psychological Research. Conceptual, Strategic, and Statistical Considerations. Journal of Personality and Social Psychology, 51(6), 1173-1182. https://doi.org/10.1037/00223514.51.6.1173

Cooper, D. R., \& Schinder, P. S. (2014). No Title (12th edition). New York: The McGraw-Hill Companies, Inc.

Diouf, D., Hebb, T., \& Toure, E. H. (2016). Exploring Factors that Influence Social Retail Investors ' Decisions: Evidence from Desjardins Fund. 45-67. https://doi.org/10.1007/s10551-0142307-4

Gardner, J. M. and J. (2004). A Comparison of Socially Responsible and Conventional Jomthm McLachlan. Journal of Business Ethics, 52(1), 11-25.

Geoffrey Williams. (2007). Some Determinants of the Socially Responsible Investment Decision: A Cross-Country Study. The Journal of Behavioral Finance, 8(1), 43. https://doi.org/10.1080/15427560709337016

Glac, K. (2008). Explaining socially responsible investing: A framing perspective of the investment decision process. ProQuest Dissertations and Theses, 200-n/a.

Glac, K. (2009). Understanding socially responsible investing: The effect of decision frames and tradeoff options. Journal of Business Ethics, 87(SUPPL. 1), 41-55. https://doi.org/10.1007/s10551008-9800-6

Glac, K. (2012). The Impact and Source of Mental Frames in Socially Responsible Investing. Journal of Behavioral Finance, 13(3), 184-198. https://doi.org/10.1080/15427560.2012.707716

Hair, J. F., Hult, G. T. M., Ringle, C. M., \& Rstedt, M. S. (2014). A Primer On Partial Least Square Structural Equation Modeling. London: Sage Publication.

Hunt, S. D., \& Vitell, S. J. (1992). The general theory of marketing ethics: A retrospective and revision. Ethics in Marketing, 775-784. 
Hunt, Shelby D., \& Vitell, S. J. (1986). A General Theory of Marketing Ethics. Journal of Macromarketing, 6(Spring), 5-16.

Hunt, Shelby D., \& Vitell, S. J. (2006). The General Theory of Marketing Ethics: A Revision and Three Questions. Journal of Macromarketing, 26(2), 143-153. https://doi.org/10.1177/0276146706290923

Hylton, M. O. (1992). "Socially responsible" investing: doing good versus doing well in an inefficient market. American University Law Review, 42(1), 1-52.

Kennedy, E. J., \& Lawton, L. (1998). Religiousness and business ethics. Journal of Business Ethics, 17(2), 163-175. https://doi.org/10.1023/A:1005747511116

Lewis, A. (2001). A focus group study of the motivation to invest: 'ethical/green'and 'ordinary'investors compared. Journal of Socio-Economics, pp. 331-341. Retrieved from http://www.sciencedirect.com/science/article/pii/S1053535701001032

Neuman, W. L. (2014). Social Reseach Methods: Quantitative and Qualitative Methods (4th ed.). Harlow: Pearson Education Limited.

Pace, S. (2013). Does Religion Affect the Materialism of Consumers? An Empirical Investigation of Buddhist Ethics and the Resistance of the Self. Journal of Business Ethics, 112(1), 25-46. https://doi.org/10.1007/s10551-012-1228-3

Pace, S. (2014). Effects of intrinsic and extrinsic religiosity on attitudes toward products: Empirical evidence of value-expressive and social-adjustive functions. Journal of Applied Business Research, 30(4), 1227-1238.

Pitz, Gordon F; Sachs, G. F. (1984). Judgment and Decision: Theory and Application. Annual Review of Psychology, 35(139-164). https://doi.org/35.020184.001035

Putra, T. S., \& Asri, M. (2018). Pengaruh Religiositas, Moral dan Love of Money Dalam Proses Pengambilan Keputusan Socially Responsible Investment. Universitas Gadjah Mada.

Renneboog, L., Ter Horst, J., \& Zhang, C. (2011). Is ethical money financially smart? Nonfinancial attributes and money flow of socially responsible investment funds. Journal of Financial Intermediation, 20(4), 562-588. https://doi.org/10.1016/j.jfi.2010.12.003

Revelli, C., \& Viviani, J. L. (2015). Financial performance of socially responsible investing (SRI) What have we learned? A meta-analysis. Business Ethics, 24(2), 158-185. https://doi.org/10.1111/beer.12076

Schneider, H., Krieger, J., \& Bayraktar, A. (2011). The Impact of Intrinsic Religiosity on Consumers' Ethical Beliefs: Does It Depend on the Type of Religion? A Comparison of Christian and Moslem Consumers in Germany and Turkey. Journal of Business Ethics, 102(2), 319-332. https://doi.org/10.1007/s10551-011-0816-y

Singhapakdi, A., Vitell, S. J., Lee, D. J., Nisius, A. M., \& Yu, G. B. (2013). The Influence of Love of Money and Religiosity on Ethical Decision-Making in Marketing. Journal of Business Ethics, 114(1), 183-191. https://doi.org/10.1007/s10551-012-1334-2

Vitell, S. J., Singh, J. J., \& Paolillo, J. G. P. (2007). Consumers' ethical beliefs: The roles of money, religiosity, and attitude toward business. Journal of Business Ethics, 73(4), 369-379. https://doi.org/10.1007/s10551-006-9212-4

Walker, A. G., Smither, J. W., \& DeBode, J. (2012). The Effects of Religiosity on Ethical Judgments. Journal of Business Ethics, 106(4), 437-452. https://doi.org/10.1007/s10551-011-1009-4

Walsh, J. P. (1995). Linked references are available on JSTOR for this article: Managerial and 
Finding the presence of God in investor's heart: examining the link between religiosity and socially responsible investment

Organizational Cognition: Notes from a Trip Down Memory Lane. Organization Science, 6(3), 280-321.

Westbrook, L. (2006). Mental models: a theoretical overview and preliminary study. Journal of Information Science, 32(6), 563-579. https://doi.org/10.1177/0165551506068134

Williams, Geoffrey. "Socially responsible investment in Asia." Social Space (2007): 20-27.

Wong, Hong Meng. "Religiousness, love of money, and ethical attitudes of Malaysian evangelical Christians in business." Journal of business ethics 81.1 (2008): 169-191. 